\title{
DROGFOGYASZTÁS ÉS FELNŐTTÉ VÁLÁS A FIATAL FELNŐTT POPULÁCIÓ KÖRÉBEN MAGYARORSZÁGON
}

\author{
DRUG USE AND TRANSITION TO ADULTHOOD \\ IN THE YOUNG ADULT POPULATION IN HUNGARY
}

\author{
Arnold Petra \\ $\mathrm{PhD}$ \\ petra.arnold@gmail.com
}

ÖSSZEFOGLALÁS

\begin{abstract}
A tanulmány célja a drogfogyasztás és a posztadoleszcencia közötti kapcsolat vizsgálata a fiatal felnőtt populáció körében. A 2010-ben készült kvalitatív kutatás a 18-34 éves, tiltott szert soha nem használók, valamint az alkalmi és problémás használók csoportjait célozza meg. Az eredmények szerint mind a három csoport mutat posztadoleszcens jellemzőket, illetve mindhárom csoport narratíváiban fellelhetőek olyan tényezők, amelyek sérülést eredményezhetnek a felnőtté válás során. Az egyes csoportok közötti különbség a posztadoleszcencia intenzitása és a felnőtté válás sérülésében való érintettség mértéke alapján érhető tetten. A problémás fogyasztók hamarabb indulnak el a felnőtté válás útján, jellemzően kényszerpályán történő mozgás miatt, és ők sérülnek leginkább a felnőtté válás során. Az alkalmi és nem használók esetében általában nem külső kényszer, hanem belső késztetés útján történnek meg a felnőtté válás irányába az első lépések, és esetükben kevésbé tapasztalhatók identitásfejlődést hátráltató tényezők. A nem fogyasztók és az alkalmi fogyasztók állnak legközelebb, és a problémás fogyasztók állnak legtávolabb a felnőttségtől.
\end{abstract}

\section{ABSTRACT}

The object of the study is to analyze the relation between drug use and post-adolescence in the young adult population. The qualitative research carried out in 2010 focuses on youth (18-34) who never used illicit drugs; who are occasional or problematic drug users. According to the results all three groups' interviewees can be described with post-adolescent features. All three groups' narratives show factors which may damage the transition to adulthood. What makes the groups different though is the degree the interviewees are involved in post-adolescence and to what extent their transition to adulthood is damaged. Problematic users move into the adult stage earlier than the other two groups' interviewees as a consequence of certain external circumstances. They are the ones being harmed the most during the transition to adulthood. On the contrary, non-users

${ }^{1}$ A tanulmányban bemutatott kutatás a Szociális és Munkaügyi Minisztérium támogatásával, a „Kábítószer-problémával kapcsolatos vizsgálatok, kutatások támogatására (KAB-KT-09)” program keretében valósult meg. 
and occasional users are not under such pressure but are motivated to make the first steps on their own to become an adult. Among non-users and occasional users there are less factors which may affect the identity development. Non-users and occasional users are the ones closest to reach the adult status and problematic users are far away of becoming adult.

Kulcsszavak: drogfogyasztás, posztadoleszcencia, identitás, kvalitatív kutatás, felnőtté válás, megalapozott elmélet

Keywords: drug use, post-adolescence, identity, qualitative research, transition to adulthood, grounded theory

\section{BEVEZETÉS}

Az új évezredben egy új típusú kultúra, civilizáció kibontakozásának vagyunk tanúi, amelyet posztmodern civilizációnak neveznek. E kibontakozóban lévő posztmodern kultúra „terméke” egy olyan ifjúság, amely életstílus, értékrend, magatartás, mentalitás tekintetében eltér a hagyományos civilizáció fiataljaitól. A tanulás, munka világában, a nemi szerepekben, a párkapcsolatokban, a szexuális magatartásban, illetve a mentalitásban történő változások mind azt mutatják, hogy egy újfajta ifjú nemzedék kialakulása figyelhető meg napjainkban, amelyet a szakirodalom új ifjúságnak (Somlai, 2007), posztadoleszcenseknek (Keniston, 1968) nevez.

Az egyes életszakaszok közötti átmenetek nehéz időszakok, ugyanis az egyénnek minden életszakaszban különböző feladatokkal, kihívásokkal kell megküzdenie (Erikson, 1968). Több elmélet is hangsúlyozza, hogy az identitásfejlődés egy életen át tartó folyamat. Azonban a legkritikusabb, legválságosabb időszaknak a serdülőkorból a felnőttkorba való átmenet tekinthető. Ebben az időszakban történik az egyik legnagyobb pszichoszociális változás: a fiatal ekkor lép ki a serdülőkorból; ekkor történik meg a szülői háztól való leválás; ekkor alakul ki az egyén életminősége, értékrendje, életmódja, identitása, vagyis az egyén helye a társadalomban; ebben az életszakaszban kell - a lehetöségek özönében - jövőt meghatározó döntéseket hoznia, elsősorban a hivatás és a párválasztás területén.

A posztadoleszcens életszakasz egy hosszabb átmenet a serdülőkor és a felnőttkor között, amikor a fiatalok bizonyos szempontból még a serdülőkhöz, más szempontból azonban már a felnőttekhez tartoznak (Vaskovics, 2000). A posztadoleszcens életszakasz a serdülökor, a serdülökori normatív krízis és az identitáskeresés időszakának elhúzódását is jelenti egyben, amely bizonytalanságot eredményez az egyén életében (Stone et al., 2012). A hosszabb átmenet egy tartósan „státusz nélküli”, „sehol nem levés” állapot (Gennep, 2007), ami szintén bizonytalansággal jár. 
A serdülőkorból a felnőttkorba való átmenet akkor tud zökkenőmentesen lezajlani, ha intézményi keretekhez kötött (Erikson, 1968), azonban a posztmodern korban a fiatalok kikerültek azon társadalmi intézmények - család, iskola, társadalmi szervezetek - alól, amelyek az előző korszakban többnyire erősen kontrollálták életüket Az Ulrich Beck (2003) által kockázat-társadalomnak nevezett új korban a lehetőségek közötti választásokhoz, döntésekhez többé már nem nyújtanak segítséget a hagyományos intézmények. Ennek eredménye, „hogy az emberek egyre mélyebben bonyolódnak az elbizonytalanodás, a kínzó kérdések és az önmagukról való megbizonyosodás labirintusába" (Beck, 2003, 177.), és egyre fontosabb számukra az önmegvalósítás, a személyes képességek kibontakoztatása. A hagyományos civilizáció fiataljai számára kiszámíthatóbb volt a jövő, amely ugyan „korlátozta az egyén szabadságát, hiszen akadályozta a helyesbítéseket és változtatásokat, de az állandóság ígéretét hordozta, és irányt adott a fiatalok előrelátásának" (Somlai, 2007, 39.). Régebben rituálék segítették az egyént az átmeneti, normatív krízises szakaszokban. A mai posztmodern társadalomban azonban hiányoznak ezek a rituálék (Demetrovics, 2010), így az egyénnek önállóan és egyedül kell megküzdenie az átmeneti élethelyzettel, hogy a következő életszakaszba léphessen. Azok a fiatalok pedig, akiknek nem sikerül megküzdeniük a fiatal felnőttkor ezen kihívásaival, a köztes, „sehol nem levés” (Gennep, 2007) bizonytalan állapotában ragadhatnak.

A fenti tényezők együttesen bizonytalanságot eredményeznek az egyén életében, ami rizikótényezőként lép fel a különböző deviáns magatartásformák megjelenése szempontjából (Stone et al., 2012).

A tanulmány célja a drogfogyasztás és a posztadoleszcencia közötti kapcsolat vizsgálata szociológiai, valamint pszichoszociális dimenziók mentén a fiatal felnőtt népesség körében. Kísérletet teszek annak bemutatására, hogy az egyes drogfogyasztói csoportok - problémás fogyasztók, alkalmi fogyasztók és nem fogyasztók - a posztadoleszcens jellemzők (szociológiai dimenzió), valamint a felnőtté válás folyamatát befolyásoló tényezők (pszichoszociális dimenzió) alapján miben mutatnak különbségeket és hasonlóságokat.

A tanulmányban először bemutatom röviden a kutatás módszerét, ezt követően az eredményeket, a következtetéseket ismertetem.

\section{MÓDSZER}

A kutatás a 18-34 éves, tiltott szert soha nem használókat (továbbiakban nem használók), alkalmi és problémás használókat célozza meg. A szülői háztól való leválás esetében Vaskovics László (2000) elméletét alkalmaztam. A posztadoleszcencia egyéb jellemzői közé a munkavállalással, tanulással, pár- 
kapcsolattal, gyermekvállalással kapcsolatos tényezőket soroltam. A kutatás pszichoszociális pillére esetében Erik H. Erikson (1968) személyiségfejlődés elméletére támaszkodtam. A problémás droghasználókat a Kábítószer és Kábítószer-függőség Európai Megfigyelőközpontja (European Monitoring Centre for Drugs and Drug Addiction, EMCDDA) definíciója alapján határoztam meg², az alkalmi használókat pedig az Egyesült Államok Marihuána- és Drogabúzus Elleni Nemzeti Bizottsága (National Comission on Marijuana and Drug Abuse) által kialakított tipizálási mód segítségével definiáltam ${ }^{3}$. Nem használóknak azokat tekintettem, akik soha életükben semmilyen tiltott szert ${ }^{4}$ nem próbáltak ki. Mind a három drogfogyasztói csoport elérése hólabda és networking technikák kombinációjával történt. A mintába kerüléshez szürőkérdőívet alkalmaztam. A kutatásban való részvétel anonim és önkéntes volt. Bruttó minta 45 fö, nettó minta 42 fö. A kutatás kombinált technikával, mcadamsi életútinterjús módszerrel, valamint face to face és önkitöltős kérdőív együttes alkalmazásával valósult meg, 2010 tavaszán. A kérdőíveket SPSS segítségével dolgoztam fel, az interjúk elemzésénél a megalapozott elméletre (GlaserStrauss, 1967) támaszkodtam.

\section{EREDMÉNYEK}

Szociológiai dimenzió

\section{Közös fedél alól történő leválás}

Az interjúalanyok döntő többsége elköltözött a szüleitől. A problémás fogyasztók vagy nagyon korán, vagy nagyon későn költöztek el otthonról. A problémás fogyasztók és a nem használók fiatalabb korban, átlagosan 18,7 évesen költöztek el otthonról, az alkalmi fogyasztók esetében valamelyest idősebben, átlagosan 21 évesen történt meg a közös fedél alól való leválás. Az eredmények arra engednek következtetni, hogy a közös otthonból való elköltözés alapján leginkább az alkalmi fogyasztók mutatnak posztadoleszcens jellemzőket.

\footnotetext{
${ }^{2}$ Problémás fogyasztó az, aki tartósan és/vagy rendszeresen fogyaszt opiát- és/vagy amfetaminszármazékokat és/vagy kokaint és/vagy bármilyen drogot intravénásan.

${ }^{3}$ Alkalmi használaton a rekreációs jellegü szerhasználatot értem. Alkalmi fogyasztóknak tekintem azokat, akik a kérdezést megelőző évben 10-51 alkalommal fogyasztottak tiltott szert.

${ }^{4}$ Tiltott szerek közé az EMCDDA ajánlásai figyelembevételével a következő szereket sorolom: kannabisz, ecstasy, amfetamin, kokain, crack, heroin, egyéb opiát, LSD, mágikus gomba, GHB. (Az újfajta pszichoaktív szerek a kutatás idején még nem robbantak be a drogpiacra.)
} 
Anyagi függetlenség

A kutatás során elért droghasználók többsége, a nem használók fele anyagilag független a szülőktől. Az egyes csoportok közötti nagyobb eltérés a támogatás mértéke tekintetében tapasztalható: a szülőktől rendszeres támogatásban részesülő nem fogyasztók havi bevételének közel fele, az alkalmi használók esetében közel kétharmada a szülőktől származik, a problémás használók bevételének csak 10\%-át teszi ki a szülői támogatás. E szempontból tehát leginkább a nem fogyasztók és az alkalmi fogyasztók mutatnak posztadoleszcens jellemzőket.

\section{Önálló döntéshozatal}

A mintába került problémás használók egyáltalán nem vonják be szüleiket a döntéshozatalba. A nem használók és az alkalmi használók fele egyedül hozza meg a döntéseket, a másik fele kikéri szülei véleményét, majd a döntést egyedül hozza meg. Ebből a szempontból tehát a nem fogyasztók és az alkalmi használók mutatnak leginkább posztadoleszcens jellemzőket, ugyanis leginkább ők vonják be szüleiket a döntéshozatalba.

\section{Öntudatosulás}

A szubjektív tényezőkre fókuszálva megállapítható, hogy a különböző fogyasztási kategóriában elért interjúalanyok közül a problémás használók mutatnak leginkább posztadoleszcens jellemzőket. E csoport tagjainak többsége nem tartja magát felnőttnek, míg a nem használók több mint fele úgy gondolja, hogy felnőtt. Az alkalmi használók a másik két csoport között helyezkednek el: kevésbé tudnak azonosulni a felnőtt képpel, mint a nem fogyasztók, de inkább mutatnak felnőttségre utaló jeleket a problémás fogyasztókhoz viszonyítva.

\section{Tanulmányok}

A nem fogyasztók és az alkalmi fogyasztók hosszabb ideig folytatják tanulmányaikat, mint a problémás fogyasztók. Az alkalmi és nem fogyasztók mindegyike rendelkezik legalább érettségivel, a problémás fogyasztók közel háromnegyedének érettségi vagy annál alacsonyabb az iskolai végzettsége. A problémás használók többsége nem jár iskolába, az alkalmi használók fele, a nem fogyasztók több mint fele jelenleg is iskolába jár. Ezen iskolai jellemzők arra utalnak, hogy leginkább az alkalmi és nem fogyasztók, s legkevésbé a problémás fogyasztók bírnak posztadoleszcens jellemzőkkel. Az integrációs elméletekkel összhangban a problémás szerhasználók iskolai integráltsága alacsonyabb fokú az alkalmi és nem használókhoz viszonyítva, és ez hatással lehet a problémás szerhasználat kialakulására is. 


\section{Munkavállalás}

A kutatás során elért problémás használók többsége jelenleg nem dolgozik, a másik két csoport többsége kereső tevékenységet folytat. Leggyakrabban a problémás használók váltanak munkahelyet, amely két tényezővel magyarázható: a posztmodern társadalom által közvetített életstílussal (könnyen, gyorsan lehet és kell változtatni), vagy a munkahelyről való eltanácsolással.

Az első rendszeres munka kezdetének átlagos életkora a problémás használók körében a legalacsonyabb: 16-17 éves korban vállalnak először munkát. A nem fogyasztók és az alkalmi használók átlagosan 20. évük környékén kezdenek el rendszeresen dolgozni. E különbség az alacsonyabb iskolai végzettségre vezethető vissza: a problémás használók az általános iskola, középiskola befejezését követően munkába állnak, a nem használók és az alkalmi fogyasztók pedig az esetek jelentős részében folytatják tanulmányaikat.

A munkaváltás gyakorisága, illetve a gazdasági aktivitás tekintetében leginkább a problémás fogyasztók mutatnak posztadoleszcens tüneteket, azonban az első rendszeres munka kezdetének átlagos életkora épphogy a másik két csoport posztadoleszcenciában való fokozott érintettségére utal. Mindemellett megfigyelhető az is, hogy a munkavállalással kapcsolatos eredmények harmonizálnak a klasszikus integrációs magyarázó elméletekkel: a munkavállalás kevésbé jelent integratív erőt a problémás használók körében a másik két csoporthoz viszonyítva, amely szerepet játszhat a problémás szerhasználat kialakulásában.

\section{Párkapcsolat}

A mintába került alkalmi és problémás fogyasztók a nem fogyasztókhoz képest fiatalabb korban létesítenek tartós, nem együtt élö, illetve élettársi kapcsolatot. Míg a nem fogyasztók kétharmada és az alkalmi fogyasztók fele jelenleg párkapcsolatban él, addig a problémás használók többsége nem él kapcsolatban. Az alkalmi fogyasztóknak volt eddig a legtöbb kapcsolatuk, amely fokozott posztadoleszcencia jelenlétére utal. Mind a három csoportban alacsony a házasulni kívánók száma, a nem fogyasztók körében a legmagasabb. A problémás fogyasztók közül négy interjúalanynak van gyermeke, a másik két csoportból senkinek nincs gyermeke. Mint ahogy a narratívákból kiderült, a problémás fogyasztók körében a gyermekvállalás nem tervezetten, a megfelelö körülményeket megteremtve, hanem spontán módon történik, amely épphogy nem a felnőtt identitásra, hanem annak hiányára vall. A párkapcsolat szempontjából az eredmények ellentmondásosak: mindegyik csoport mutat posztadoleszcens jellemzöket, de összességében leginkább a drogfogyasztók. 
Pszichoszociális dimenzió

\section{Marginalizálódás}

A narratívákban a marginalizálódás két megjelenési formája - a problémás viselkedés és a beilleszkedési nehézségek - fordul elő. A marginalizáció észlelése mentén húzható meg a problémás viselkedés és a beilleszkedési nehézségek közötti különbség: az elöbbi esetben a kirekesztett helyzetet az interjúalanyok jellemzően nem észlelik - ők a „,tudattalan kirekesztettek”, az utóbbi esetben az interjúalanyok a marginalizált helyzetet észlelik - ők a „tudatos kirekesztettek”. A marginalizált pozíció, a társas kirekesztettség - akár tudatos, akár tudattalan marginalizációról van szó - gátló tényezőt jelenthet az identitásfejlődésben (Conger, 1991) mind a három vizsgált csoportban.

A problémás fogyasztók majdnem mindegyike beszámol valamilyen problémás viselkedésről, de az alkalmi használók túlnyomó többségénél és a nem használók kevesebb mint felénél is előfordulnak problémás tünetek. Az iskolai közegbe való beilleszkedési problémák leginkább az alkalmi és a nem használók körére jellemzők: míg a nem használók és az alkalmi használók több mint fele, addig a problémás fogyasztók közül csupán néhányan élnek meg beilleszkedési nehézségeket. A problémás fogyasztók többsége tehát „tudattalan kirekesztett”, a nem használókra és az alkalmi fogyasztókra pedig fokozottabban jellemző a ,tudatos kirekesztettség".

\section{Diszfunkcionális családmodell}

A narratívák azt mutatják, hogy serdülőkorban a problémás használók majdnem mindegyike, az alkalmi használók többsége és a nem használók kevesebb mint fele a diszfunkcionális családmodell különböző aspektusairól számol be, amelyek gátló tényezőt jelenthetnek a személyiségfejlődésben. Az egyes drogfogyasztói csoportok közötti különbség a diszfunkcionális tünetek súlyosságában és intenzitásában érhető tetten. A problémás fogyasztók körében - a másik két csoporthoz viszonyítva - fokozottabban jellemző a fizikai és szóbeli agresszió jelenléte a családban. Ezzel szemben a nem használók és az alkalmi használók majdnem mindegyike olyan családban nevelkedik, amely érzelmi biztonságot nyújt számára, noha ez a két csoport is beszámol diszfunkcionális tünetek jelenlétéröl. A nem használók és alkalmi használók körében a szülök nevelési módszere szabadabb, engedékenyebb, következetesebb a problémás fogyasztókhoz képest. Ez a nevelési módszer, korábbi kutatások szerint, egyrészt megfelelő táptalaja a személyiségfejlődésnek, a felnőtté válásnak, másrészt a problémás szerhasználat során is védőfaktort jelenthet. A problémás használók körében megfigyelhető diszfunkcionális tünetek (mint például agresszió, autokrata nevelés, túlzó óvás, az anyával való szimbiózis kapcsolat, az apa lelki és/vagy fizikai jelen nem léte) a korábbi kutatásokkal (Demetrovics, 2007) összhangban, a felnőtté válásban és 
a droghasználat problematikus voltának megszüntetésében is gátló tényezőt jelenthetnek.

A problémás használók egy része serdülőkorban a szülők fizikai és/vagy lelki jelen nem léte miatt hirtelen felnövésre, érettségre kényszerül, amellyel nehezen tud megbirkózni. Az interjúalanyok másik részére jellemző a kölcsönös függőség, a leválásra való képtelenség mind a szülők, mind a problémás használók részéről. „Mindez azt jelenti, hogy a drogosok kirekesztése nem abban az értelemben jellemző, hogy a szülői társadalom, a mikrokörnyezet szegregálja öket a társadalmi környezettől, hanem abban, hogy akadályoztatja öket az életciklusuknak adekvát társadalmilag normatív leválás, autonómia megvalósításában" (Vingender, 2006, 175.).

A problémás fogyasztókkal szemben a másik két vizsgált csoport alanyai felnőttkorukra érzelmi függetlenséget, a szülőkkel harmonikus kapcsolatot tanúsítanak. Mindazonáltal néhány alkalmi és nem használó körében megfigyelhető, hogy a szülők nehezítik a leválást, a függetlenedést, nincsenek felkészülve az elengedésre, amely az alanyok számára szintén nehezítő tényezőt jelent a felnőtté válás folyamatában (Conger, 1991).

\section{Krizishelyzetek}

Mindhárom drogfogyasztói csoportra jellemző, hogy az interjúalanyok többségének az életében előfordul törés, krízis. Az egyes csoportok közötti különbség a törések intenzitásában, típusában, illetve az azokkal való megküzdés módjában van. A problémás használók körében figyelhető meg a legtöbb törés. Az ő szerhasználatuk jellemzően egy-egy traumaként megélt esemény után válik intenzívvé. Az interjúk során gyakran tapasztaltam, hogy a párkapcsolati szakítást a problémás használók nehezebben dolgozzák fel a nem használókhoz, illetve az alkalmi fogyasztókhoz viszonyítva, s ennek eredményeként intenzívebbé válik a drogfogyasztás. Néhány esetben előfordul, hogy a munkahely elvesztése törést jelent az interjúalany számára, amely - és több más tényező - eredményeként (újra) a drogokhoz fordul. Ez ellentmond Vingender István (2006) megállapításának, mely szerint a munka elvesztése a droghasználó számára kevésbé traumatikus élmény, mint a nem használók számára.

Az alkalmi és nem használók életében a problémás fogyasztókhoz hasonlóan előfordulnak törések, átmenetek. Az alkalmi és nem használók mintegy fele az érettségit követő válságos időszakról számol be, amely jellemzően a pályaválasztásban való elbizonytalanodás, a lakóhelyváltozás (kisvárosból nagyvárosba való költözés), az egyetem befejezése utáni tartósabb munkanélküliség miatt alakul ki. Az alkalmi és nem használók körében posztadoleszcencia jelenlétére utal, hogy fiatal felnőttkorban serdülőkori krízishez hasonló tünetek jelentkeznek. Ez a válságos időszak pánikrohamban, szorongásos tünetekben, intenzívebb szer- és/vagy alkoholhasználatban nyilvánul meg. Mindez megerősíti azt a korábbi megállapí- 
tást, mely szerint az átmenet bizonytalansággal jár együtt, amely nagyobb rizikót jelent a szerhasználat, a deviáns magatartás szempontjából (Stone et al., 2012). Az elbizonytalanodás hátterében feltehetően egyrészt a társadalom által generált választások és lehetőségek sokaságának útvesztője áll, másrészt az elbizonytalanodás oka lehet az is, hogy a társadalom egy olyan képet közvetít, mely szerint a döntések nem véglegesek, gyorsan és könnyen lehet váltani, változtatni a munkában, szakmában, hivatásban, a kapcsolatokban (Somlai, 2013). Harmadrészt, az oktatási rendszer müködésével is magyarázható a fiatalok elbizonytalanodása, ugyanis az oktatási rendszer nemigen segíti elő az iskolai átmenetet: a fiatalok gyakran úgy választanak egy szakképzési irányt, hogy pontosan nem tudják, mit szeretnének csinálni, illetve nincsenek tisztában azzal, hogy az adott szakképzés mit takar. A fenti tényezők nehezítik a fiatalok dolgát egy stabil identitás kialakításában, azaz a mai kor ifjú generációjának nehéz feladata van, amikor arra a kérdésre keresi a választ, hogy „Ki vagyok én?” (Somlai, 2013).

Az alkalmi és nem fogyasztók többsége - a problémás szerhasználókkal szemben - nem ragad benne a krízishelyzetekben. A krízishelyzetekkel jellemzően sikerül megküzdeniük, és a törések építően hatnak személyiségükre: a személyiségük töréspontok, átmenetek mentén formálódik és fejlődik. Az alkalmi és nem fogyasztók több mint fele arról számol be, hogy személyiségfejlödésen ment keresztül, ezzel szemben csupán egy problémás szerhasználó narratívája utal személyiségfejlődésre. Míg az alkalmi és nem fogyasztók a krízishelyzetet saját erővel, életvitel változtatással, önismeret-fejlesztéssel stb. küzdik le, addig a problémás szerhasználók intenzívebb szerhasználatot, azaz a belső elhárító mechanizmusok (elfojtás, tagadás) kiegészítéseképpen „drogelhárítást” alkalmaznak (Conger, 1991) a krízises helyzetek kezelésére. Ennek következményeként a krízishelyzetet követően a problémás használók még erősebb komplexusokkal, önértékelési problémákkal küszködnek, amely gátló tényezőt jelent az egyéni identitás megtalálásában (Conger, 1991). A problémás szerhasználók körében a korábbi kutatási eredményekkel (Conger, 1991) összhangban megküzdő képesség hiánya, maladaptív viselkedés figyelhető meg. Ezzel szemben az alkalmi és nem használókra jellemző a változásokra, kihívásokra való gyors és adaptív reagálás, a hatékony stresszkezelés, illetve megküzdő képesség, amelyek az érett személyiség indikátorának is tekinthetőek.

\section{KÖVETKEZTETÉSEK}

„A drogfogyasztó posztadoleszcens-e?” kérdésre részben igennel és részben nemmel tudok felelni - a kutatás eredményei alapján. Mind a három csoport mutat posztadoleszcens jellemzőket - megerősítve Somlai Péter (2013) megállapítását, mely szerint mára tömegével fordulnak elő a posztadoleszcens fiatalok. Jelen 
vizsgálat eredményei arra engednek következtetni, hogy a posztadoleszcencia egy teljesen önálló életszakasznak tekinthető. Mindhárom csoport narratíváiban fellelhetőek olyan tényezők, amelyek sérülést eredményezhetnek a felnőtté válás során. Az egyes csoportok közötti különbség tehát nem a posztadoleszcenciában való érintettség vagy nem érintettség szerint, hanem a posztadoleszcencia intenzitása és a felnőtté válás sérülésében való érintettség mértéke alapján érhető tetten.

A problémás fogyasztók hamarabb indulnak el a felnőtté válás útján, azonban - mint ahogy a narratív elemzés mutatja - jellemzően nem saját döntés eredményeként, hanem a kényszerpályán történő mozgás miatt. Azért költöznek el otthonról, mert el kell költözni, azért hozzák meg egyedül a döntést, mert nincsenek jó viszonyban a szüleikkel, vagy nem is ismerik öket; azért kezdenek el korán dolgozni, mert anyagilag rászorulnak; azért váltanak gyakran munkahelyet, mert a munkáltató elbocsátja őket, stb.

Az alkalmi és nem használók esetében általában nem külső kényszer, hanem belső késztetés útján történnek meg a felnőtté válás irányába az első lépések, és a mikrokörnyezet (család, iskola) támogatóbb a felnőtté válásban. A kényszer valamilyen szinten az alkalmi és nem használók körében is jelentkezik a társadalmi anomáliákból fakadóan: a lakásnélküliség, a munkanélküliség, a kedvezőtlen anyagi háttér nem saját döntés, hanem kényszerhelyzet eredménye, amely hátráltató tényezőt jelent a felnőtté válás útján. Az ebből fakadó frusztráció, feszültség eltérő magatartásmódokat generálhat, és nagyobb kockázatot jelenthet a deviáns viselkedések szempontjából. A társadalmi anomáliák miatt az alkalmi és nem használók körében a középiskola-egyetem átmenet fokozottan válságos időszaknak bizonyul, amely - a korábbi megállapításokat megerösítve - felhívja a figyelmet arra, hogy az iskolai átmenet, a felnőttkorba való átmenet szerhasználattól függetlenül nehéz időszak.

A problémás használók „kényszer felnőtté válásának” eredménye, hogy jelen pillanatban ők tekinthetőek legkevésbé felnőttnek, ők sérülnek leginkább a felnőtté válás útján, és a problémás használók körében a legjellemzőbb a kölcsönös függőség, a leválásra való képtelenség mind a szülők, mind a problémás használók részéről. A problémás használók jellemzően egy krízishelyzetben ragadt, státusz nélküli, ,sehol nem levés” állapotban vannak. A problémás szerhasználók esetében a szociális kirekesztés, a munka, iskola stb. világából való izoláltság erős háttértényezője lehet egyrészt a szerhasználat, másrészt a posztadoleszcencia kialakulásának és fennmaradásának, a felnőtt identitás csorbulásának. „A posztadoleszcens élethelyzet önmagában is reprezentálhatja a kirekesztés jelenségét, hiszen olyan megfosztottságot tükröz, amely az önállósodás, a szülői családtól való fizikai-szociális emancipáció folyamatát gátolja, illetve odázza el" (Vingender, 2006, 175.). Mindezek együttesen - a szerhasználat, a posztadoleszcencia, a szociális kirekesztés - a hátrányos helyzet halmozódását 
erősítik fel. A problémás fogyasztókkal szemben az alkalmi használók és a nem használók inkább mutatnak felnőttségre utaló jeleket, esetükben kevésbé tapasztalhatóak identitásfejlődést hátráltató faktorok, továbbá független, harmonikus kapcsolatuk van a szüleikkel. Jelen kutatás eredményei Kapitány Balázs (2006) megfigyeléseit támasztják alá: a posztadoleszcencia sokkal inkább egy kényszerpályán mozgó folyamat, amely a hátrányos társadalmi körülmények miatt válik tartóssá.

A kutatás eredményei jelzik, hogy a posztadoleszcens jellemzők a fiatal felnőtt populációban általánosan jelen vannak, és az ezzel járó bizonytalanság, a fentebb említett átmeneti nehézségek szerhasználattól függetlenül tetten érhetőek a fiatalok körében. A posztadoleszcens jellemzők fokozottabb jelenléte azonban elősegítheti a problémás szerhasználat kialakulását. Az eredmények megerősítik azt is, hogy az egészséges énkép, a megküzdő képesség, az önreflexió, az önismeret mind olyan tényezők, amelyek segítenek az átmenet átvészelésében, a felnőtté válásban, illetve abban is, hogy a szerhasználat kontrollált maradjon. Mindez felhívja a figyelmet az önismeretre, a megküzdő képesség fejlesztésére irányuló prevenciós programok fontosságára. A kutatás eredményei továbbá felhívják a figyelmet arra, hogy mind az elsődleges, mind a másodlagos szocializációs közegnek meghatározó szerepe van az egyén identitásfejlödésében, valamint a droghasználat tekintetében, nemcsak serdülőkorban, hanem a középiskola és az egyetem közti átmeneti időszakban is. Ezért fontos lenne, hogy a preventív beavatkozások serdülökorra, és az egyetem eleji, fiatal felnőttkorra is kiemelt figyelmet fordítsanak.

\section{IRODALOM}

Beck, U. (2003): A kockázat-társadalom. Út egy másik modernitásba. (ford. Berényi G., Kerékgyártó Gy.) (Andorka-Sorozat) Budapest: ARTT-Századvég Politikai Iskola Alapítvány

Conger, J. J. (1991): Adolescence and Youth. Psychological Development in a Changing World. New York: HarperCollins

Demetrovics Zs. (2007): A droghasználat funkciói. Budapest: Akadémiai Kiadó

Demetrovics Zs. (2010): A megszaladás jelenségének szerepe az addiktológiai zavarok értelmezésében. In: Csányi V. - Miklósi Á. (szerk.): Fékevesztett evolúció. Megszaladási jelenségek az emberi evolúcióban. Budapest: Typotex Kiadó, 135-160.

Erikson, E. H. (1968): Identity Youth \& Crisis. London: Faber \& Faber

Gennep, A. V. (2007): Átmeneti rítusok. (ford. Vargyas Z.) Budapest: L'Harmattan Kiadó

Glaser, B. G. - Strauss, A. L. (1967): The Discovery of Grounded Theory: Strategies for Qualitative Research. Chicago: Aldine DOI 10.1097/00006199-196807000-00014, http://www.sxf. uevora.pt/wp-content/uploads/2013/03/Glaser_1967.pdf

Kapitány B. (2006): Objektív és szubjektív tényezök a felnőtté válás átalakuló folyamatában. Elöadás. Andorka Rudolf Emlékkonferencia, Budapest, 2006. október 9-10.

Keniston, K. (1968): Young Radicals. New York: Harcourt, Brace \& World, https://archive.org/ details/youngradicalsnot00keni 
Somlai P. (2007): A posztadoleszcensek kora. Bevezetés. In: Somlai P. (szerk.): Új ifjúság - Szociológiai tanulmányok a posztadoleszcensekröl. Budapest: Napvilág Kiadó, 9-45. http://www. fszek.hu/szociologia/somlai/somlai_peter_a_posztadoleszcensek_kora.pdf

Somlai P. (2013): Család 2.0. Együttélési formák a polgári családtól a jelenkorig. Budapest: Napvilág Kiadó

Stone, A. L. - Becker, L. G. - Huber, A. M. et al. (2012): Review of Risk and Protective Factors of Substance Use and Problem Use in Emerging Adulthood. Addictive Behaviours, 37, 747-775. DOI: 10.1016/j.addbeh.2012.02.014

Vaskovics L. (2000): A posztadoleszcencia szociológiai elmélete. Szociológiai Szemle, 10, 4, 3-20. http://www.szociologia.hu/dynamic/0004vaskovics.htm

Vingender I. (2006): Adalékok a droghasználat társadalmi mintázatához. Addictologia Hungarica $5,3,161-190$. 